\title{
Who supports gender quotas in Ireland?
}

\author{
Lisa Keenan \\ Gail McElroy \\ likeenan@tcd.ie \& \\ mcelroy@tcd.ie
}

\begin{abstract}
Candidate gender quotas were passed into law in the Republic of Ireland in 2012. This paper examines support for this quota among three different groups: local election candidates, a sample of professionals and the general public. Using responses from three different datasets, we identify the key ideological, partisan and demographic predictors of support for the quota. We find the single best predictor of support for the quota is, not surprisingly, the gender of the respondent, followed by feminist ideology. There is a weak effect for left-wing ideology and partisanship and for beliefs regarding the causes of women's absence from political life. Overall, the results suggest that resistance to the quota is still relatively strong amongst both potential candidates for Dáil Éireann and the Irish electorate.
\end{abstract}

Keywords: Gender Quotas; Candidate Selection; Party Politics; Irish Elections

\section{Introduction}

The Electoral (Amendment) (Political Funding) Act 2011 was passed into law by Oireachtas na hÉireann in July of 2012. In addition to reforming the system of corporate donations to political parties, the legislation also introduced a 30 per cent gender quota for parties in general elections. Any party failing to comply with the quota would, subsequently, lose half of their state funding for a full parliamentary term. While gender quotas, in their diverse forms, are common throughout the democracies of Europe, very often public demand for the introduction of these types of gender equality measures is not significant. In the United Kingdom, for example, a majority of both men and women, 63 and 51 per cent respectively, reported opposing the introduction of all-women shortlists for candidate selection (Wells 2014). In Ireland, the subject of women's underrepresentation was an issue largely outside the public domain prior to the introduction of the quota measure and the measure was also strongly resisted by significant elements within the established political parties, most particularly incumbents within Fianna Fáil. As such, the 
passage of the legislation was a little surprising; given it was both unpopular with considerable numbers of elected officials and not an obvious vote-winner. Speaking at the final stage of the bill in the Seanad, the Minister for the Environment Mr. Phil Hogan explained his reasons for bringing forward the contentious measure with the following comment:

"..women are under-represented and have been since the foundation of the State and the situation will not change unless action is taken. This is what we have done. The Bill has charted a complex path in balancing our legal and constitutional responsibilities against a clear need and desire to bring about significant change (Seanad Debates 20/07/2012).

Of the many strategies that are available to parties and policy-makers to address the continued under-representation of women in elected office, the adoption of a legislative quota is one of the most ambitious as well as the most controversial (see Lovenduski, 1993 for a discussion). In this paper, we explicitly examine support for the legislation amongst political and professional elites, as well as the general public in the Republic of Ireland. To date, the literature on support for gender quotas has tended to focus almost exclusively on the aggregate party level, but in this paper we examine individual level variation in support. We address this through the use of two original datasets surveying the attitudes of the type of individuals most likely to run for office in Ireland (educated professionals and local election candidates, the so-called 'eligibility pool') and data from the Irish National Election Study, which surveys the views of the Irish public. In what follows, we first explore the theoretical expectations surrounding support for gender quotas and derive several testable hypotheses based on this. We next describe the data we gathered to examine these propositions. Finally, we present the results of our analysis and conclude with a brief general discussion of the implications of our study.

\section{Literature}

Quota measures to increase women's representation have become increasingly popular in parliaments around the world. In 2011, Ireland joined a group of over one hundred countries that operate quotas of one form or another; in 2016 the number of countries with legal quotas stands at $\mathbf{7 7}$, while 50 more have voluntary party quotas (Quota Database 2016). In line with their popularity as policy instruments, a relatively large 
academic literature on gender quotas has emerged examining issues such as the many forms they can take, their overall impact on the numbers of women elected and the subsequent impact of increased numbers of women legislators on substantive representation. A more limited literature within this field explores the determinants of gender quota adoption and here the findings fall into four broad categories (Celis et al 2011). First, there are the standard accounts that explain quota adoption as a function of the mobilisation of women's groups (Bruhn 2003; Kittilson 2006). Second, there are strategic accounts, in which political parties advocate the adoption of quotas in order to gain favour with women voters (Matland and Studlar 1996; Meier 2004). Third, a body of work on newly democratized countries explores the role of outside pressure from international organizations to introduce quotas (Htun and Jones 2002). Finally, adoption is explained as a function of a party's or country's general ideological commitment to equality, whereby parties of the left and egalitarian societies, such as those in northern Europe, typically advocate for their introduction (Caul 2001; Krook et al 2009). Further work on the impact of party ideology on quota introduction has also found that religious ideology matters, with traditionalist Catholic parties opposing quotas in Poland, while anti-clerical parties favour them (Dubrow 2010). Finally, it has also been found that party structure and organization matter (Short 1996; Caul, 2001; Bruhn, 2003); having women among the ranks of party leadership is associated with the adoption of quotas. With respect to the level of internal democracy of parties, the results are mixed. Bruhn (2003 p. 116) takes the optimistic view that the existence of transparent and relatively democratic decision-making procedures leaves out-groups scope to "push for changes without the sponsorship of the party hierarchy or a powerful reformer". Other authors find that in practice quotas do not flourish where intra-party democracy is high (Kenny \& Verge 2013; Childs 2013). In this paper we aim to further explore this topic of who advocates for quotas by examining individual level variation in support for the measure.

In the few instances where individual legislators have been surveyed about their attitudes to quotas, gender emerges as the key predictor of support. For instance, Lovenduski and Norris (2003) find that, controlling for background and party, female Westminster MPs are more likely to favour the use of positive quotas to get women elected when compared with their male counterparts and this result is echoed by Dubrow (2010) for 
the Polish Sejm. Similarly, in Mexico, Baldez (2004) found that a cross party coalition amongst female politicians was key to the successful adoption of a gender quota law in 2002. These specific results on quotas fit with a larger body of work on women legislators' attitudes to affirmative action and welfare policies targeted towards women as a group. For instance, Childs and Withey (2004) find that Labour women MPs are far more likely to introduce early day motions that are favourable to women and similar work on the US by Swers (2002) finds that women, irrespective of party affiliation, are more likely to sponsor women's issue bills.

While this literature represents an important scholarly contribution to understanding why it is that gender quotas are being adopted despite resistance from several quarters both inside and outside political parties, the tendency to focus on parties' and, to a lesser extent, legislators' means we still know relatively little about support for gender quotas more generally. This paper employs original data sources to construct an eligibility pool for Dáil Éireann and examines the attitudes towards the gender quota amongst the type of people who will be future legislators. It further makes a contribution to the literature by studying the impact of previously unexamined explanatory variables, namely beliefs about the causes of women's underrepresentation, and also by comparing the results from our eligibility pool sample to those from a random sample of the electorate through the use of the 2011 Irish National Election Study data.

\section{Hypotheses}

The primary research question that this paper seeks to answer can be formally stated as: what predicts support for the gender quota amongst potential candidates and members of the general public? Our review of the literature led us to formulate five main hypotheses relating to support for this measure. The first two hypotheses are straightforward and simply predict that those most concerned and affected by women's under representation are most likely to support quotas.

H1: Women should have higher levels of support for the gender quota than men. 
$\mathrm{H}$ 2: Identification as a feminist should be positively related to support for the gender quota.

Hypotheses 1 argues that women should, all else equal, be more in favour of the measure since it will increase women's presence in the Dáil, improving their level of representation in descriptive terms, which in turn should lead to greater substantive representation for women, that is in terms of the advocacy they receive in parliament with respect to their interests (see Pitkin, 1967 for a discussion of these concepts). Evidence of a gender gap in support for party quotas has been found previously among Polish parliamentarians (Dubrow 2010) and also in the general population in Gidengil's (1996) study of attitudes towards quotas in a Canadian setting. We expect that women in the eligibility pool will be more likely to support the gender quota: this increased likelihood of support relates not only to the perceived advantages of having a candidate who looks like them on the ballot (see Pitkin, 1967) but also to increased opportunities for their candidacy should they be inclined to stand. ${ }^{1}$ Conversely, their male counterparts should regard the quota measure with suspicion and hostility.

Hypothesis two predicts that those who identify as feminists should be more inclined to support a legislative measure that directly challenges male-domination of politics in Ireland. Prior research employing data from twenty-four Latin American countries finds that holding gender egalitarian attitudes increases support for gender quotas, independent of the respondent's gender (Barnes \& Córdova 2016).

Hypotheses 3, 4 and 5 attempt to test how beliefs about why women are under represented affect support for gender quotas:

H3: A belief that underrepresentation occurs because parties do not create opportunities for women should be positively related to support for the gender quota.

\footnotetext{
${ }^{1}$ Gender quotas may be a particularly powerful tool for the election of women in Ireland, given the nature of the electoral system, where parties have little to no say over which candidates from the ballot are elected. This can be contrasted with the experiences of even open list systems such as Poland (Górecki and Kukołowicz 201) or Brazil (Miguel 2008).
} 
H4: A belief that underrepresentation occurs because voters prefer male candidates should be positively related to support for the gender quota.

H5: A belief that underrepresentation occurs because not enough women come forward should be negatively related to support for the gender quota.

We anticipate that respondents' beliefs about the cause of women's relative absence from Irish politics will impact their level of support for the gender quota. Prior research in this area has examined whether men and women have different perspectives on the factors that explain women's underrepresentation. Meier $(2008,338)$ uncovers a gender gap in these attributions, concluding that "[men"...locate the explanations for women's underrepresentation at the level of the individual woman while women seek the causes at a structural level". However, the author does not explore the extent to which these attributions explain support for gender quotas and whether they might do so over and above respondent sex; our paper addresses this gap. From the existing literature on the causes of women's underrepresentation in political life, we select three separate sources of potential obstruction to women's candidacy: parties, voters and women themselves. The first two correspond to important components of the demand for female candidates by gatekeepers, while the latter corresponds to the so-called supply side of these candidacies (Norris \& Lovenduski 1995; Norris 1997). The supply of candidates and demands of gatekeepers correspond to two of the four levels in the so-called 'funnel of causality' (the others being the political system - constant in the context of a single country analysis - and the recruitment process) that captures the process by which political recruitment occurs. Those who believe that few women are active in political life due to a lack of demand by parties [H3] and voters [H4] should be should be more likely to support the quota, than those who think that the cause is a lack of supply for parties and voters to select from. In this latter case, the cause for women's political underrepresentation is that they do not put themselves forward [H5], possibly because women are simply not as interested in politics as men or lack the competitive edge. This latter hypothesis tests the impact of respondents' adherence to gender essentialist views. 
It should be noted that these beliefs about the causes of women's underrepresentation should impact on level of support for quotas regardless of whether the attributions made by the respondents are correct. For instance, a belief that the electorate is biased against women candidates can exist in the absence of any empirical evidence to support this conviction. Indeed, existing evidence from survey data and election results tells us that in Ireland the electorate does not appear to discriminate against female candidates (McElroy \& Marsh, 2010; 2011). Irish political parties meanwhile have been pointed to as having been slow to prioritise the recruitment of women (Galligan 1993; Lakeman 1994; McGing 2013) and even to exhibit a masculine culture which fails to foster the progression of those that are recruited (Connolly 2013). That Irish parties appear to play an important role in suppressing women's candidacies does not preclude respondents believing that the fault lies elsewhere. We reiterate therefore that these three hypotheses assess the overall impact of perceptions of the causes of women's underrepresentation on level of support only.

\section{Data:}

To examine the above hypotheses we draw on three separate datasets: an original survey of candidates from the 2014 local elections, a survey of professionals and the Irish National Election Study of 2011. The first two datasets, the 2014 Local Election Candidate Study (LECS) and the 2013 Political Attitudes and Experiences (PAE) survey can be considered as studying the attitudes to gender quotas amongst those most likely to run for office, the so called 'eligibility pool' (Lawless and Fox 2005). The third dataset captures attitudes amongst the general public. The first two datasets have been designed and implemented by the authors. We are interested in the attitudes of these groups - the eligibility pool and voters more generally - since the quota is likely to affect them in different ways. For the voter, a quota that is successfully implemented renders the candidates that he or she can choose from more diverse; the impact for voters therefore is in the area of representation. For those individuals who are most likely to stand, the quota not only impacts their choice at the ballot box as voters but may also alter their incentives to stand. 
With respect to the eligibility pool, the obvious question that arises is how does one define a pool of likely candidates for office? In the related literature there are two possible methods for doing this: either by selecting the occupations that are highly represented among legislators and sampling individuals from those professions (after Fox, Lawless \& Feeley, 2001), or by surveying those individuals who are already politically active (after Davidson-Schmich, 2008). Both approaches have particular limitations in the Irish case. Firstly, though it is true that we can identify certain occupations that are over-represented in the Dáil, they are not over-represented to the extent that they are in the United States, where legal and business backgrounds dominate. Secondly, Ireland's rate of political party membership is lower than the EU average (van Biezen, Mair \& Poguntke, 2012), and parties do not have a monopoly on candidates' routes to power since individuals can also run as independents. In order to address these limitations, data from both sources have been employed. Individuals located in key occupations (i.e. those that are overrepresented in Dáil Éireann), as well as candidates at the 2014 local election were used to construct an eligibility pool. With respect to the local election candidates, it is worth noting that experience at local government has long represented a path to national office in Ireland. At the 1992 general election, only 9.6 per cent of TDs had never had local government experience (Gallagher, 1993), while at the 2011 general election 128 of non-incumbent party candidates were local councillors (Reidy, 2011).

The first dataset (LECS) represents a survey of the entire population of candidates in the May 2014 local elections in Ireland. In total, 2007 questionnaires were sent out with 810 usable responses returned to the research team, giving a response rate of 40.36 per cent. $^{2}$ As illustrated in Figure 1 the composition of the sample in terms of the respondents by party is very close to that of the population with Independents and Fianna Fáil very slightly underrepresented.

FIGURE 1 ABOUT HERE

\footnotetext{
${ }^{2} 2022$ candidates were on the ballot paper at the 2014 local election. Two were withdrawn before the election but after each ward had completed its notice of poll and 13 of the candidates' addresses could not be retrieved.
} 
Similarly, we find that while 21.76 per cent of total candidates were women, they made up 23.09 per cent of respondents in our sample. We are reasonably satisfied therefore that the sample obtained closely approximates the population from which it was drawn.

The second dataset is the sample of professionals (PAE). This was a mail based survey conducted in the Summer of 2013 amongst a random sample of 2500 people working in the education (school principals, heads of university departments), health (doctors, dentists), and legal professions (barristers and lawyers) in the Republic of Ireland, plus people employed at a senior level in business (CEOs, chartered accountants) and policy sectors (directors and senior researchers in think thanks). ${ }^{3}$ An equal number of male and female professionals were sampled. These five sectors currently increasingly represent the main gateway careers for elected officials in Ireland (Gallagher and Marsh 2011). As such these respondents can be considered as representing the pool of potential candidates for election in Ireland. 732 usable responses were returned to the research team, yielding a response rate of 29.28 per cent. Of those who responded, 45.22 per cent were women. The 16-page survey asked respondents about their political attitudes and experiences, their perceptions of public life, their socio-economic demographics and childhood education and home-life and finally the survey also probed their general outlook on life.

The third dataset used in the analysis is the Irish National Election Survey 2011. This survey was conducted in the immediate aftermath of the February 2011 general election. In total, 1800 respondents were surveyed face to face, with interviews typically lasting an hour. There was also a drop-off questionnaire, amounting to a further 15 minutes that was completed by about 90 per cent of respondents. This data is used to capture the attitudes of the general public to quotas.

\section{The Eligibility Pool Analysis}

In this section we examine the evidence for our hypotheses using the LECS and PAE datasets. The dependent variable for both the datasets is a Likert-type scale capturing the response to the following question: 'how much do you support the use of gender quotas for

\footnotetext{
${ }^{3}$ Unusually by comparative standards, a full 19 per cent of sitting TDs (2011-2016) are teachers.
} 
national elections?' Respondents in both surveys were informed that candidate gender quotas would be introduced in Ireland at the next general election. This statement was included in order to provide context for survey participants. For the LECS, the dependent variable is measured on an eleven-point scale (from 0 [strongly oppose] to 10 [strongly support]); while, the PAE uses an eight-point scale. Figures 2 and 3 illustrate the distribution of the dependent variable for the LECS and PAE samples respectively. We can see that there is substantial variation in the local election candidate sample, with the vast majority of respondents having very strong feelings about it (the plurality response categories are strongly opposing or strongly supporting it). If we add those giving a response of 0,1 or 2 (strongly opposed) we find that over a third of the sample is distinctly resistant to the introduction of quotas, with a further 28 per cent strongly in favour (response of 8,9 or 10). The professional sample also exhibits a range of attitudes towards the quota, though these are more evenly spread across the categories than in the LECS sample. This may be, in part, an artefact of the smaller scale being used or the timing of the study (2013), with attitudes towards the quota more crystallized by 2014 . It may also be that those running for elected office have stronger views on the issue, given its relevance to their candidacy and their overall levels of politicization.

\section{FIGURES 2 and 3 ABOUT HERE}

The key independent variables to test $\mathrm{H} 1$ and $\mathrm{H} 2$ are gender and identification as a feminist. The former takes value 1 if the respondent is a woman and 0 otherwise, while the latter takes value 1 if the respondent self-identifies as either a 'feminist' or a 'strong feminist' and 0 if they identify as 'not a feminist' or 'anti-feminist. ${ }^{4}$

H3-H5 test whether respondents' beliefs about the causes of women's underrepresentation in political life matter for level of support for the gender quota. To reiterate, where respondents attribute their absence to structural factors that are beyond the control of women, they should be more likely to support the quota measure. Where

\footnotetext{
${ }^{4}$ Employing the full scale of this variable did not alter the regression results.
} 
they attribute it to women's failure to put themselves forward, they should be less likely to support it. Three variables, all measured on a five-point Likert scale, are included to capture beliefs about why underrepresentation arises. Respondents were asked the extent to which they agreed or disagreed with the following statements: 1) 'women are not given fair opportunities by parties' 2) 'most voters prefer male candidates' and 3) 'not enough women come forward to be considered as candidates'. Respondents who attribute women's absence to their failure to put themselves forward should be less likely to support quotas (H5), while those who attribute it to party or voter bias ( $\mathrm{H} 3$ and $\mathrm{H} 4)$ should be more inclined to do so.

We additionally control for a series of other variables that are likely to impact on attitudes to quota introduction. This extant literature on the topic generally finds that party ideology is the single most important predictor of support for quotas. Unsurprisingly, parties on the left tend to be more likely to favour quotas - by adopting them within the party and/or advocating for them to be introduced on a compulsory basis for all parties in the political system - compared to those located to the right of the political spectrum (Caul, 2001; Bruhn, 2003; Htun \& Power, 2006). Thus we control for individual's left-right selfplacement in both the LECS and PAE models. This variable was measured on an eleven-point scale from 0 (left) to 10 (right). It was anticipated that those on the left would be more likely to be in favour of the measure, while those on the right should be more likely to oppose it. ${ }^{5}$

For the local election candidates, several additional factors were expected to matter for level of support. First, level of political experience may impact candidates' evaluations of the measure. Those who have more political experience might see the quotas as a threat to the status quo and thus be less likely to support them, while those with little or no political experience might be more positive about them. Variables capturing previous candidacy (taking a value of 1 if the individual has previously run for elected office at any level and a value of 0 otherwise) and incumbency (where a value of 1 indicates an incumbent) were therefore included. We also control for the type of candidate. As the gender quota only applies to those who stand as candidates for political parties, we might expect support for

\footnotetext{
${ }^{5}$ Dubrow's (2010) paper highlighted the importance of religious ideology in predicting party support for gender quotas. Initial models (not presented here) included a variable capturing religiosity, measured as the frequency of attendance at religious services. Religiosity of individual respondents did not prove to be significant and has therefore been omitted in the final models.
} 
quotas to differ along party/non-party lines. One model includes a party candidate dummy (taking a value of 1 if the candidate is standing for a political party, and a value of 0 if the candidate is an independent), while a second model includes the following party categories in the place of the dummy: Fine Gael, Fianna Fáil, Labour, Sinn Féin, other party (including the Green Party, the United Left Alliance, and People Before Profit), and non-party. ${ }^{6}$ This latter model is included in the analysis since, as has been noted above, attitudes towards quotas should differ across parties. Level of education is also included in the models, ranging from primary education only through to doctoral degree.

In the professionals' sample we additionally include a measure of political engagement, as this is expected to influence views on legislative measures in general. Respondents who follow politics more closely may have stronger views on the measure since they are more likely to be aware of what exactly the measure is and also the debate surrounding the issue. Respondents in the PAE sample were asked "how closely do you follow national politics?' and responses were measured on a four-point scale from 1 (not closely) to 4 (very closely). Additionally, propensity-to-vote scores were included to capture respondent closeness to particular political parties. Supporters of smaller and more leftwing parties (notably Labour and Sinn Féin) should feel more positively towards the quota measure, since such parties have historically had higher levels of female representation and have been more likely to support measures to address gender imbalances. Supporters of centre-right parties that tend to be dominated by men should be less likely to believe that women's underrepresentation is an issue that needs addressing and, where they do, should be unlikely to favour affirmative action measures to address the problem. We expect supporters of Fianna Fáil in particular to have lower levels of support for the measure. The scores were calculated by asking respondents to indicate on a scale from 0 to 10 how probable it is that they would vote for a particular party at the next election. This value was then divided by ten in order to create propensity scores between 0 and 1 .

The hypotheses were tested using a series of ordered logit regression models. Table 1 provides the results from the local election candidate sample, and Table 2 presents the results from the professionals' sample. All four models lend support to Hypothesis 1: being

\footnotetext{
${ }^{6}$ Due to the low number of respondents from several of the smaller parties, these parties were grouped together for the purposes of the regression analysis.
} 
a woman increases the probability of supporting the gender quota in both samples. Similarly, Hypothesis 2 is supported by all four of the models: identifying as a feminist, all else equal, increases support for the gender quota. The effect of these two variables is rather substantial. For instance, the probability that a local election candidate who is a woman and a feminist (all else equal) will strongly support (a score of 8,9 or 10 on the scale) gender quotas is 0.48 , compared with a probability of just 0.11 for a local election candidate who is a man and not a feminist (using model 1 coefficients). ${ }^{7}$ The respective probabilities for the PAE sample for the same comparison (using model 3 coefficients and a score of 6 or 7 on the quota support scale) are 0.26 and 0.11

\section{TABLES 1 AND 2 ABOUT HERE}

Across all four models there is clear support for Hypothesis 3: where members of the eligibility pool attribute women's absence from politics to the lack of opportunities created for them by political parties, they are more likely to support the gender quota. With respect to Hypothesis 4, we obtain no significant coefficients. It is worth noting, however, that these coefficients are also not in the expected direction. We find that a belief that voters prefer male candidates is negatively related to support for the gender quota. Hypothesis 5 is not supported by these results either. For the LECS sample, the coefficients are in the expected direction (negative) but they are not statistically significant. For the PAE sample, by contrast, the coefficients in Models 3 and 4 are statistically significant, at the 0.001 and 0.01 per cent levels respectively, but in the opposite direction to that hypothesised. Here, a belief that not enough women put themselves forward to be considered as candidates is positively associated with support for the gender quota.

This result is somewhat puzzling since we had anticipated that blaming women for their absence from Irish politics would mean that respondents were less inclined to support measures targeted at facilitating their entry into political life. One possible explanation for this unexpected result may be that this question does not actually measure blaming women themselves for their underrepresentation as cleanly as the research team had anticipated. It is possible, for example, that individuals in the PAE sample believe not only that not enough

\footnotetext{
${ }^{7}$ Odds ratios for all models in the paper are provided in tables $1 \mathrm{~A}-\mathrm{C}$ in the appendix.
} 
women come forward but also that the reason that they will not come forward is due to a host of factors over which they have no control (traditional causes cited in the literature are unequal distribution of labour in the household, a lack of support network and other resources etc. [see Sapiro, 1982; Clark, 1991; Norris \& Lovenduski, 1993 for discussion of these person-centred accounts]). Support for a gender quota in such circumstances would not be counterintuitive. However, this is purely speculative and requires further analysis with a better specified survey instrument. The limitation of the survey instrument is that we cannot know how respondents interpreted the question. Indeed, there is evidence that respondents may interpret questions in surveys in a manner that is very different from that intended by the research team and indeed in ways that are very different from one another (Suessbrick, Schober, \& Conrad, 2000).

With respect to our controls, in the local election sample, incumbency and prior political experience were not significant predictors of support for the gender quota. However, being a party candidate was actually found to matter in Model 1. Holding everything else constant, moving from being an independent to a party candidate was found to increase the probability of supporting the gender quota by an average of 18.7 per cent. Education was also insignificant. For the PAE sample, level of political engagement was not found to be significantly related to support. However, some interesting results emerge when we consider partisan effects. Right wing self-placement was found to be negatively related to support for the gender quota in both Models 1 and 3, as expected. Those who self identify as left-wing are more likely to support the introduction of quotas. However, only the coefficient for the PAE model was statistically significant: for this group, as individuals move from the left to the right of the political spectrum, support for the gender quota falls. We find similar results for the models containing party identification and the propensity to vote scores. Though none of the coefficients in the candidate model are significant, they are, broadly speaking, in the expected direction: Labour and Sinn Féin exhibit positive coefficients, while the Fianna Fáil coefficient is negative. For the professional sample, three of the propensity to vote scores achieved significance. Having a higher likelihood of voting for the Labour Party or Sinn Féin at the next election was associated with increased levels of support for the gender quota, while reporting a higher propensity to vote for Fianna Fáil was associated with a reduction in support. 


\section{Analysis from the INES}

In the final set of analyses we ask whether these results hold more broadly in the general population. Data are taken from the Irish National Election Study of 2011. In this analysis the dependent variable is an indirect measure of support for candidate gender quotas. Unfortunately, no specific quota question was asked as the legislation had not yet been enacted and indeed was not a significant part of the narrative of the 2011 campaign. In this analysis we thus use respondents' answers to the following statement: 'parties should be forced to nominate more women candidates.' It should be noted that not only is this item an imperfect proxy for gender quota support, the way in which the statement is phrased may be problematic. We know that framing the same question in different ways can produce inconsistent responses (Tversky \& Kahneman 1981). Here, it is possible that the use of the word 'forced' in this item as opposed to a more neutral expression has somewhat biased the responses. We must be doubly cautious therefore in making claims about the comparability of the general population results and those from the eligibility pool sample.

Responses were measured on a 7-point scale, where 1 is strongly disagree and 7 is strongly agree. Fig. 4 shows the distribution of this dependent variable. The distribution is, as with many survey measures of the general populace, centred around the mid point (neither agree nor disagree) with a rightwards skew towards favouring parties being forced to introduce measures to select women. 48 per cent of respondents agree with the statement compared with only 22 per cent who oppose it.

\section{FIGURE 4 ABOUT HERE}

As before, gender is a key independent variable in the analysis. There is no direct measure of respondents' identification as a feminist. Instead, a respondent's feminist orientation is approximated by asking them to indicate on a 7-point scale the extent to which they agree with the statement: 'In general things would improve if there were more women in politics.' This is certainly not a perfect proxy for feminist views but we argue that disagreeing with the statement suggests that the respondent is not a feminist. The full scale is included in 
the regression models. Unfortunately, there are also no variables in the INES to capture beliefs about the causes of women's absence from political life, and no suitable proxies were available. As a result, we cannot compare the findings of this sample to those of the eligibility pool with respect to hypotheses 3-5.

Since left-right orientation and support for particular political parties are also expected to influence respondents' inclination to agree that parties should be forced to nominate more women as candidates, variables capturing both were included in separate models. Left-right self-placement is again measured on an 11-point scale from left (0) to right (10). Support for political parties was measured by calculating propensity to vote scores in the manner outlined above. Since those with high levels of political knowledge might have stronger views about this issue, we included this as a control. Political knowledge is an index composed of four objective measures of knowledge about politics (e.g. 'What was the name of the main opposition party prior to the recent 2011 election?'). The maximum score on the variable is 4 for those who correctly answered all four questions correctly. Level of education was included as a control for social class, in line with the LECS analysis.

The results from this sample support Hypotheses 1 and 2, being female and a feminist (as categorized using the proxy measure) is associated with higher levels of agreement that parties should be made to select more female candidates. As before, the effect of being a feminist and female have a large impact on support for gender quotas. The probability that a female respondent who is a feminist (a score of 7 on the proxy scale) will agree with the statement that parties should be forced to nominate women (a score of 6 or 7) is 0.58 compared with a probability of just 0.1 for male respondent who is not a feminist (a score of 1 on the proxy scale).

The control variables exhibit some unexpected relationships. Education, the proxy for social class, is negatively related to the dependent variable: those with higher levels of education are less likely to agree that parties should be forced to select more female candidates. The form of the question used to measure the dependent variable may be largely responsible for this result. At no point is the phrase 'gender quota' mentioned in the INES survey. It may be the case that those with higher levels of education are aware that 
'forcing' a party to select more female candidates would probably require the use of a legislative quota and, knowing this, they are less likely to report agreement with the statement. However, the political knowledge item was included to control for this so this variable may simply be functioning as a measure of social class, rather than capturing any greater understanding of the ways in which a party might be forced to select a higher proportion of women. We might tentatively conclude therefore that agreement that parties should be made to select more female candidates appears to be generally lower among those belonging to higher socio-economic groups.

\section{TABLES 3 ABOUT HERE}

The results that are perhaps most interesting are those related to partisanship. Right-wing self-placement in Model 5 (though non-significant) is positively correlated with a belief that parties should be forced to nominate more women; this result is at odds with the negative correlation found in the PAE and LEC models. Even more significantly, propensity to vote Fine Gael in Model 6 is correlated with high levels of agreement that more women candidates should be chosen by parties. How do we explain these findings? It may be a case of omitted variable bias, since we do not have any information regarding the respondents' beliefs about the causes of women's underrepresentation in Irish political life. However, this Fine Gael effect in particular may also be a product of the election campaign of 2011. As Buckley (2013) notes, Fine Gael's election manifesto contained a 'rhetorical' commitment to increasing women's political participation, a commitment, which was also present in the 2011-2016 programme for government (Fine Gael \& Labour Party 2011: 4). The relationship between right-wing self-identification and supporting quotas is therefore likely to be a Fine Gael one, rather than an ideological effect. The negative but non-significant coefficient for propensity to vote for Fianna Fáil lends further support to this suggestion.

\section{Conclusion}

Overall, we find that support for the gender quota is not especially high. The crosstabulations of the dependent variables show that a majority of respondents either oppose 
the introduction of the quota or report having low levels of support for it (especially when explicitly asked about it). The regression analysis tells us that gender along with identifying as a feminist are the two best predictors of support for this measure. The former result with respect to gender is in line with prior research in other contexts that finds that women are more supportive of quotas as a measure to improve women's access to political office (see Gidengil 1996; Dubrow 2010). Similarly, the positive impact of feminist orientation on support for the gender quota fit with Barnes and Córdova's (2016) findings with respect to the impact of what they term 'gender egalitarian attitudes'. The results with respect to leftright self-placement and party identification are mixed. The results from the eligibility pool are in the expected direction but only significant for the sample of professionals. For the INES models, we find evidence of a positive and significant Fine Gael effect only. We do not find the consistent result for left ideology that we had anticipated and which has been reported elsewhere (Barnes \& Córdova 2016). Most likely this finding is due to the particularities of the 2011 election in Ireland and does not represent a challenge to prior research that finds an important effect for placement on the left of the political spectrum. Finally, a belief that women's underrepresentation in politics arises due to a lack of opportunities created for them by political parties are also consistently found to matter.

What this means is that gender quotas in Ireland appear to garner support only from the usual suspects. It is particularly noteworthy that we find that supporters of one of the largest political parties, Fianna Fáil, tend to oppose the measure in line with our expectations. There does not appear to be broad consensus among the eligibility pool that men's overrepresentation in Irish political life is something that should be addressed by the imposition of a legislative quota, and even where a quota is not mentioned as a specific policy measure, less than 50 per cent of the electorate sampled agree to some extent that Irish political parties should be forced to nominate more women candidates.

We conclude by noting that while support for the measure is currently relatively low it may not necessarily remain so. Though Meier (2008) argues that a gap in support for such a policy can persist between the micro (individual politician) and macro level of politics, this may not necessarily apply to our Irish sample (not least because we have examined the attitudes of voters and potential future TDs rather than existing members of Dáil Éireann). It may be that the vast majority of individuals are sceptical before the quotas are enacted but 
that their successful enforcement - and the attendant increase in the proportion of women elected to Dáil Éireann - at the 2016 general election will cause a re-evaluation of attitudes relating to affirmative action strategies in general and this policy in particular. Bhavnani's (2009) analysis of electoral data in India finds that the effects of reserving seats for women in local Indian legislatures persist even after the quotas are withdrawn: parties continue to put women on the ticket, and voters who were initially reluctant to cast their vote for a woman become more likely to vote for them. That paper demonstrates that the implementation of a quota for even a brief period of time can have lasting effects on the attitudes of political parties and voters. It remains to be seen whether the same will be true of the Irish case. 


\section{References}

Baldez, L. (2004). Elected bodies: The gender quota law for legislative candidates in Mexico. Legislative Studies Quarterly, 29(2), 231-258.

Barnes, T. D., \& Córdova, A. (2016). Making Space for Women: Explaining Citizen Support for Legislative Gender Quotas in Latin America. The Journal of Politics, 78(3): 670-686.

Bhavnani, R. R. (2009). Do electoral quotas work after they are withdrawn? Evidence from a natural experiment in India. American Political Science Review, 103(01): 23-35.

Bruhn, K. (2003). Whores and lesbians: political activism, party strategies, and gender quotas in Mexico. Electoral Studies, 22(1): 101-119.

Buckley, F. (2013). Women and politics in Ireland: the road to sex quotas. Irish Political Studies, 28(3): 341-359.

Caul, M. (2001). Political parties and the adoption of candidate gender quotas: a crossnational analysis. Journal of Politics, 63(4): 1214-1229.

Celis, K., Krook, M. L., \& Meier, P. (2011). The rise of gender quota laws: Expanding the spectrum of determinants for electoral reform. West European Politics, 34(3), 514-530.

Childs, S., \& Withey, J. (2004). Women representatives acting for women: sex and the signing of early day motions in the 1997 British parliament.Political Studies, 52(3), 552-564.

Childs, S. (2013). Intra-party democracy: a gendered critique and a feminist agenda. In W. Cross \& R. Katz (Eds.). The Challenges of Intra-Party Democracy. Oxford University Press.

Clark, J. (1991). Getting There: Women in Political Office. Annals of the American Academy of Political and Social Science. American Feminism: New Issues for a Mature Movement, 5(15): 63-76.

Connolly, E. (2013). Parliaments as gendered institutions: the Irish Oireachtas. Irish Political Studies. 28(3): 360-379.

Davidson-Schmich, L. (2008). Gender quotas and political ambition: Evidence from Germany. Paper presented at MPSA Annual National Conference, Chicago, IL.

Dubrow, J. K. (2010). The importance of party ideology: Explaining parliamentarian support for political party gender quotas in Eastern Europe. Party Politics, 17(5): 561-579.

Fine Gael \& Labour Party. (2011). Towards Recovery: Programme for a National Government 2011-2016.

Fox, R. L., Lawless, J. L. \& Feeley, C. (2001). Gender and the Decision to Run for Office. Legislative Studies Quarterly, 26(3): 411-435.

Gallagher, M. (1993). The Election of the $27^{\text {th }}$ Dáil. In M. Gallagher \& M. Laver (Eds.) How Ireland Voted 1992. Dublin: PSAI Press. 
Gallagher, M. (2005). Ireland: The discreet charm of PR-STV. In M. Gallagher. \& P. Mitchell (Eds.) The politics of electoral systems. Oxford University Press.

Galligan, Y. (1993). Party politics and gender in the Republic of Ireland. In J. Lovenduski \& P. Norris (Eds.). Gender and party politics. London: SAGE Publications Limited.

Gidengil, E. (1996). Gender and attitudes toward quotas for women candidates in Canada. Women \& Politics, 16(4): 21-44.

Górecki, M. A., \& Kukołowicz, P. (2014). Gender quotas, candidate background and the election of women: A paradox of gender quotas in open-list proportional representation systems. Electoral Studies, 36(1): 65-80.

Htun, M. N., \& Jones, M. P. (2002). Engendering the right to participate in decision-making: Electoral quotas and women's leadership in Latin America.

Htun, M., \& Power, T. J. (2006). Gender, parties, and support for equal rights in the Brazilian Congress. Latin American Politics and Society, 48(4): 83-104.

Kenny, M., \& Verge, T. (2013). Decentralization, political parties, and women's representation: evidence from Spain and Britain. Publius: The Journal of Federalism, 43(1): 109-128.

Kittilson, M. C. (2006). Challenging parties, changing parliaments: Women and elected office in contemporary Western Europe. Ohio State University Press.

Krook, M. L., Lovenduski, J., \& Squires, J. (2009). Gender quotas and models of political citizenship. British Journal of Political Science, 39(4), 781-803.

Lakeman, E. (1994). Comparing political opportunities in Great Britain and Northern Ireland. In Rule, W. \& Zimmerman, J. F. (Eds.). Electoral systems in comparative perspective: their impact on women and minorities. London: Greenwood Press.

Lawless, J. L., \& Fox, R. L. (2005). It takes a candidate: Why women don't run for office. Cambridge University Press.

Lovenduski, J. (1993). 'Introduction: the dynamics of gender and party'. In Lovenduski, J., \& Norris, P. (Eds.). Gender and party politics. London: SAGE Publications Limited.

Lovenduski, J., \& Norris, P. (2003). Westminster women: The politics of presence. Political studies, 51(1): 84-102.

Matland, R. E., \& Studlar, D. T. (1996). The contagion of women candidates in singlemember district and proportional representation electoral systems: Canada and Norway. The Journal of Politics, 58(03), 707-733.

McElroy, G., \& Marsh, M. (2010). Candidate gender and voter choice: analysis from a multimember preferential voting system. Political Research Quarterly, 63(4): 822-833. 
McElroy, G., \& Marsh, M. (2011). Electing women to the Dáil: gender cues and the Irish voter. Irish Political Studies, 26(4): 521-534.

McGing, C. 2013. The single transferable vote and women's representation in Ireland. Irish Political Studies, 28(3): 322-340.

Meier, P. (2008). A gender gap not closed by quotas: the renegotiation of the public sphere. International Feminist Journal of Politics, 10(3): 329-347.

Miguel, L. F. (2008). Political representation and gender in Brazil: Quotas for women and their impact. Bulletin of Latin American Research, 27(2): 197-214.

Norris, P. (1997). Passages to power: Legislative recruitment in advanced democracies. Cambridge University Press.

Norris, P. \& Lovenduski, J. (1993). 'If Only More Candidates Came Forward': Supply-Side Explanations of Candidate Selection in Britain. British Journal of Political Science, 23(3): 373408.

Norris, P., \& Lovenduski, J. (1995). Political recruitment: Gender, race and class in the British Parliament. Cambridge University Press.

Pitkin, H. F. (1967). The concept of representation. London : Cambridge

Reidy, T. (2011). Candidate selection. In M. Gallagher \& M. Marsh (Eds.). How Ireland Voted 2011: The full story of Ireland's earthquake election. Basignstoke: Palgrave Macmillian.

Sapiro, V. (1982). Private Costs of Public Commitments or Public Costs of Private Commitments? Family Roles versus Political Ambition. American Journal of Political Science, 26(2): 265-279.

Short, C. (1996). Women and the Labour party. Parliamentary Affairs, 49(1), 17-26.

Suessbrick, A. L., Schober, M. F. \& Conrad, F. G. (2000) Different respondents interpret ordinary questions quite differently. In: Proceedings of the American Statistical Association (Section on Survey Research Methods). American Statistical Association. [MFS]

Swers, M. L. (2002). The difference women make: The policy impact of women in Congress. University of Chicago Press.

Tversky, A., \& Kahneman, D. (1981). The framing of decisions and the psychology of choice.Science, 221(4481): 453-458.

van Biezen, I., Mair, P., \& Poguntke, T. (2012). Going, going,...gone? The decline of party membership in contemporary Europe. European Journal of Political Research, 51(1): 24-56. 
Table 1. LECS sample - predictors of support for gender quota

\begin{tabular}{|c|c|c|}
\hline & Model 1 & Model 2 \\
\hline \multirow[t]{2}{*}{$\overline{\text { Female }}$} & $0.84^{* * *}$ & $0.81^{* * *}$ \\
\hline & $(0.19)$ & $(0.19)$ \\
\hline \multirow[t]{2}{*}{ LR self-placement } & -0.04 & \\
\hline & $(0.03)$ & \\
\hline \multirow[t]{2}{*}{ Party candidate } & $0.42^{*}$ & \\
\hline & $(0.18)$ & \\
\hline \multirow[t]{2}{*}{ Previous candidate } & 0.21 & 0.21 \\
\hline & $(0.18)$ & $(0.18)$ \\
\hline \multirow[t]{2}{*}{ Incumbent } & -0.07 & -0.14 \\
\hline & $(0.18)$ & $(0.18)$ \\
\hline \multirow[t]{2}{*}{ Feminist } & $1.09^{* * *}$ & $1.11^{* * *}$ \\
\hline & $(0.17)$ & $(0.16)$ \\
\hline \multirow[t]{2}{*}{ Level of education } & 0.00 & -0.02 \\
\hline & $(0.04)$ & $(0.04)$ \\
\hline \multirow[t]{2}{*}{ No opportunities from parties } & $0.50^{* * *}$ & $0.50^{* * *}$ \\
\hline & $(0.07)$ & $(0.07)$ \\
\hline \multirow[t]{2}{*}{ Voters prefer men } & -0.11 & -0.07 \\
\hline & $(0.08)$ & $(0.07)$ \\
\hline \multirow[t]{2}{*}{ Women don't come forward } & -0.13 & -0.11 \\
\hline & $(0.08)$ & $(0.08)$ \\
\hline \multirow[t]{2}{*}{ Fianna Fáil } & & -0.30 \\
\hline & & $(0.22)$ \\
\hline \multirow[t]{2}{*}{ Labour Party } & & 0.37 \\
\hline & & $(0.25)$ \\
\hline \multirow[t]{2}{*}{ Sinn Féin } & & 0.45 \\
\hline & & $(0.27)$ \\
\hline \multirow[t]{2}{*}{ Other party } & & -0.04 \\
\hline & & $(0.29)$ \\
\hline \multirow[t]{2}{*}{ Independents } & & -0.37 \\
\hline & & $(0.22)$ \\
\hline$\overline{\mathrm{AIC}}$ & 2428.36 & 2573.13 \\
\hline $\mathrm{BIC}$ & 2516.06 & 2675.35 \\
\hline Log Likelihood & -1194.18 & -1263.57 \\
\hline Deviance & 2388.36 & 2527.13 \\
\hline Num. obs. & 593 & 629 \\
\hline
\end{tabular}

${ }^{* * *} p<0.001,{ }^{* *} p<0.01,{ }^{*} p<0.05$ 
Table 2. Professionals sample - predictors of support for gender quota

\begin{tabular}{|c|c|c|}
\hline & Model 3 & Model 4 \\
\hline \multirow[t]{2}{*}{ Female } & $0.44^{* *}$ & $0.49^{* *}$ \\
\hline & $(0.16)$ & $(0.16)$ \\
\hline \multirow[t]{2}{*}{ LR self-placement } & $-0.16^{* * *}$ & \\
\hline & $(0.04)$ & \\
\hline \multirow[t]{2}{*}{ Feminist } & $0.62^{* * *}$ & $0.51^{* *}$ \\
\hline & $(0.17)$ & $(0.17)$ \\
\hline \multirow[t]{2}{*}{ No opportunities from parties } & $0.91^{* * *}$ & $0.86^{* * *}$ \\
\hline & $(0.08)$ & $(0.09)$ \\
\hline \multirow[t]{2}{*}{ Voters prefer men } & -0.12 & -0.10 \\
\hline & $(0.07)$ & $(0.08)$ \\
\hline \multirow[t]{2}{*}{ Women don't come forward } & $0.31^{* * *}$ & $0.32^{* *}$ \\
\hline & $(0.09)$ & $(0.10)$ \\
\hline \multirow[t]{2}{*}{ Political engagement } & -0.11 & -0.08 \\
\hline & $(0.08)$ & $(0.09)$ \\
\hline \multirow[t]{2}{*}{ Vote Fine Gael } & & -0.17 \\
\hline & & $(0.27)$ \\
\hline \multirow[t]{2}{*}{ Vote Fianna Fáil } & & $-0.70^{* *}$ \\
\hline & & $(0.23)$ \\
\hline \multirow[t]{2}{*}{ Vote Labour Party } & & $0.75^{* *}$ \\
\hline & & $(0.29)$ \\
\hline \multirow[t]{2}{*}{ Vote Sinn Féin } & & $0.87^{*}$ \\
\hline & & $(0.37)$ \\
\hline \multirow[t]{2}{*}{ Vote Green Party } & & 0.44 \\
\hline & & $(0.26)$ \\
\hline \multirow[t]{2}{*}{ Vote Independent } & & -0.21 \\
\hline & & $(0.27)$ \\
\hline \multirow[t]{2}{*}{ Vote ULA } & & 0.24 \\
\hline & & $(0.41)$ \\
\hline AIC & 2450.00 & 2302.90 \\
\hline $\mathrm{BIC}$ & 2513.19 & 2391.87 \\
\hline Log Likelihood & -1211.00 & -1131.45 \\
\hline Deviance & 2422.00 & 2262.90 \\
\hline Num. obs. & 674 & 632 \\
\hline
\end{tabular}


Table 3. INES sample - predictors of support for forcing parties to select more women

\begin{tabular}{|c|c|c|}
\hline & Model 5 & Model 6 \\
\hline \multirow[t]{2}{*}{ Female } & $0.22^{*}$ & $0.23^{*}$ \\
\hline & $(0.11)$ & $(0.11)$ \\
\hline \multirow[t]{2}{*}{ LR self-placement } & 0.06 & \\
\hline & $(0.03)$ & \\
\hline \multirow[t]{2}{*}{ Feminist (proxy) } & $0.38^{* * *}$ & $0.37^{* * *}$ \\
\hline & $(0.04)$ & $(0.04)$ \\
\hline \multirow[t]{2}{*}{ Level of education } & $-0.13^{* *}$ & $-0.13^{* *}$ \\
\hline & $(0.05)$ & $(0.05)$ \\
\hline \multirow[t]{2}{*}{ Political knowledge } & -0.10 & -0.06 \\
\hline & $(0.06)$ & $(0.06)$ \\
\hline \multirow[t]{2}{*}{ Vote FG } & & $0.55^{* *}$ \\
\hline & & $(0.21)$ \\
\hline \multirow[t]{2}{*}{ Vote FF } & & -0.21 \\
\hline & & $(0.18)$ \\
\hline \multirow[t]{2}{*}{ Vote Lab } & & -0.24 \\
\hline & & $(0.22)$ \\
\hline \multirow[t]{2}{*}{ Vote Sinn Féin } & & 0.23 \\
\hline & & $(0.21)$ \\
\hline \multirow[t]{2}{*}{ Vote Green } & & -0.51 \\
\hline & & $(0.27)$ \\
\hline \multirow[t]{2}{*}{ Vote Independents } & & -0.07 \\
\hline & & $(0.21)$ \\
\hline \multirow[t]{2}{*}{ Vote ULA } & & -0.10 \\
\hline & & $(0.34)$ \\
\hline AIC & 3851.15 & 3848.31 \\
\hline $\mathrm{BIC}$ & 3906.08 & 3933.17 \\
\hline Log Likelihood & -1914.58 & -1907.16 \\
\hline Deviance & 3829.15 & 3814.31 \\
\hline Num. obs. & 1089 & 1087 \\
\hline
\end{tabular}


Fig. 1. Party composition of LECS data

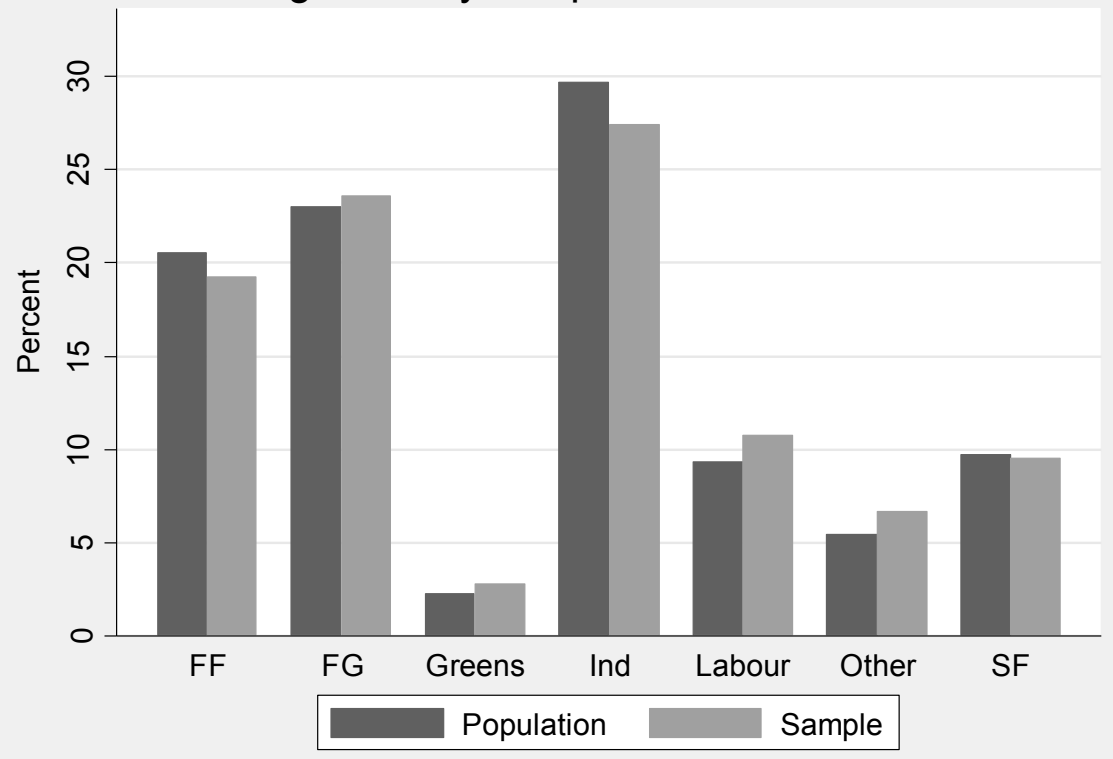




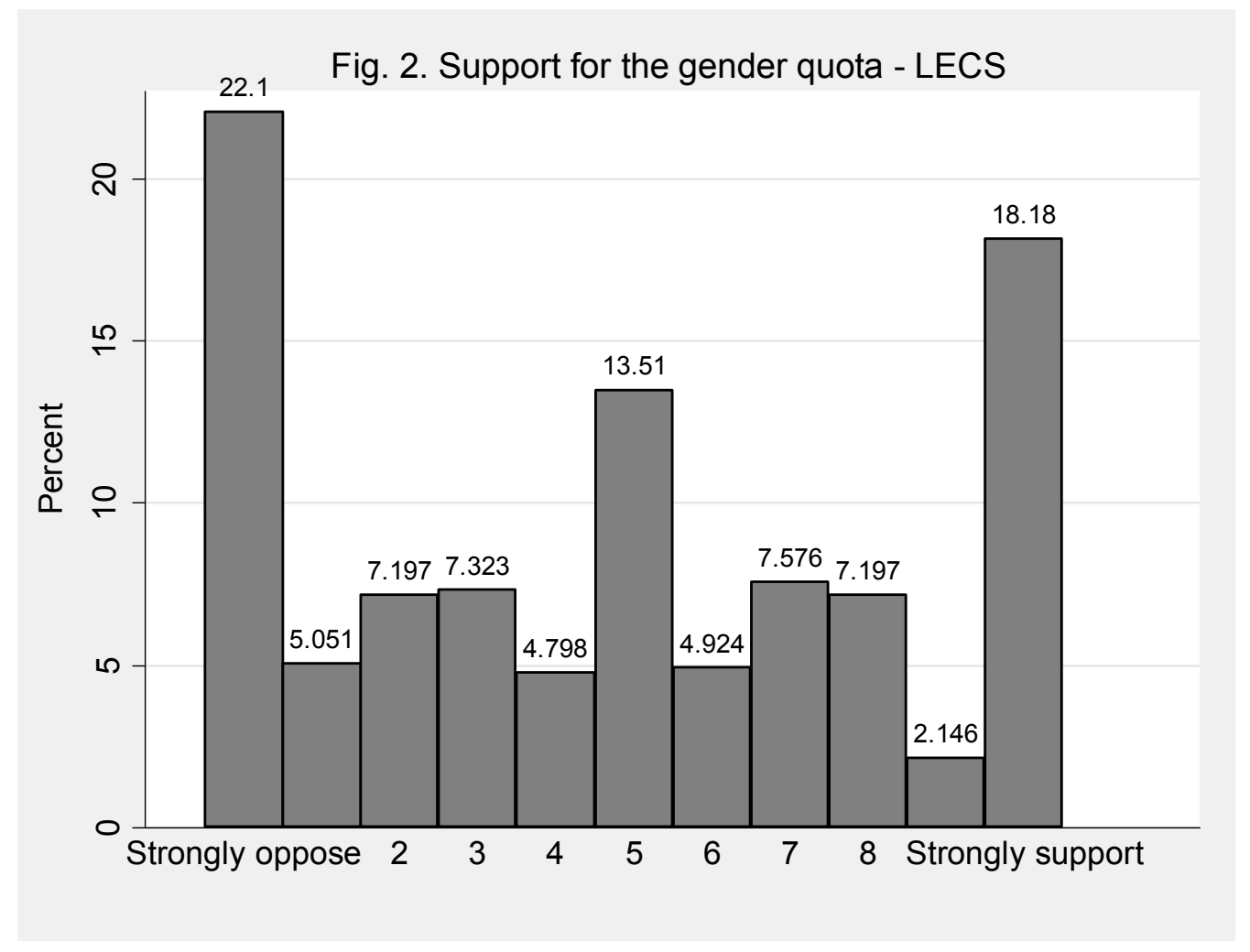


Fig. 3. Support for the gender quota - PAE

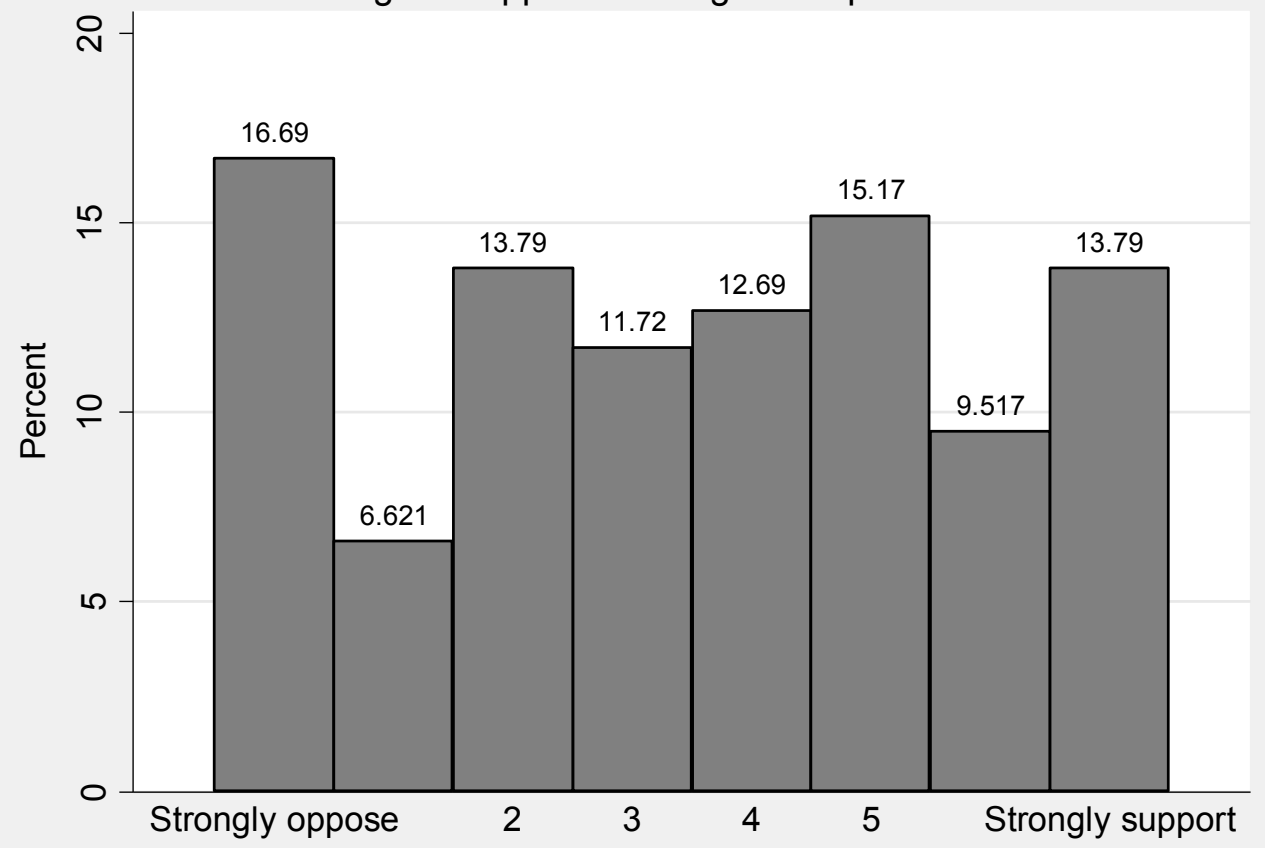

Fig. 4. Support for forcing parties to nominate more women - INES

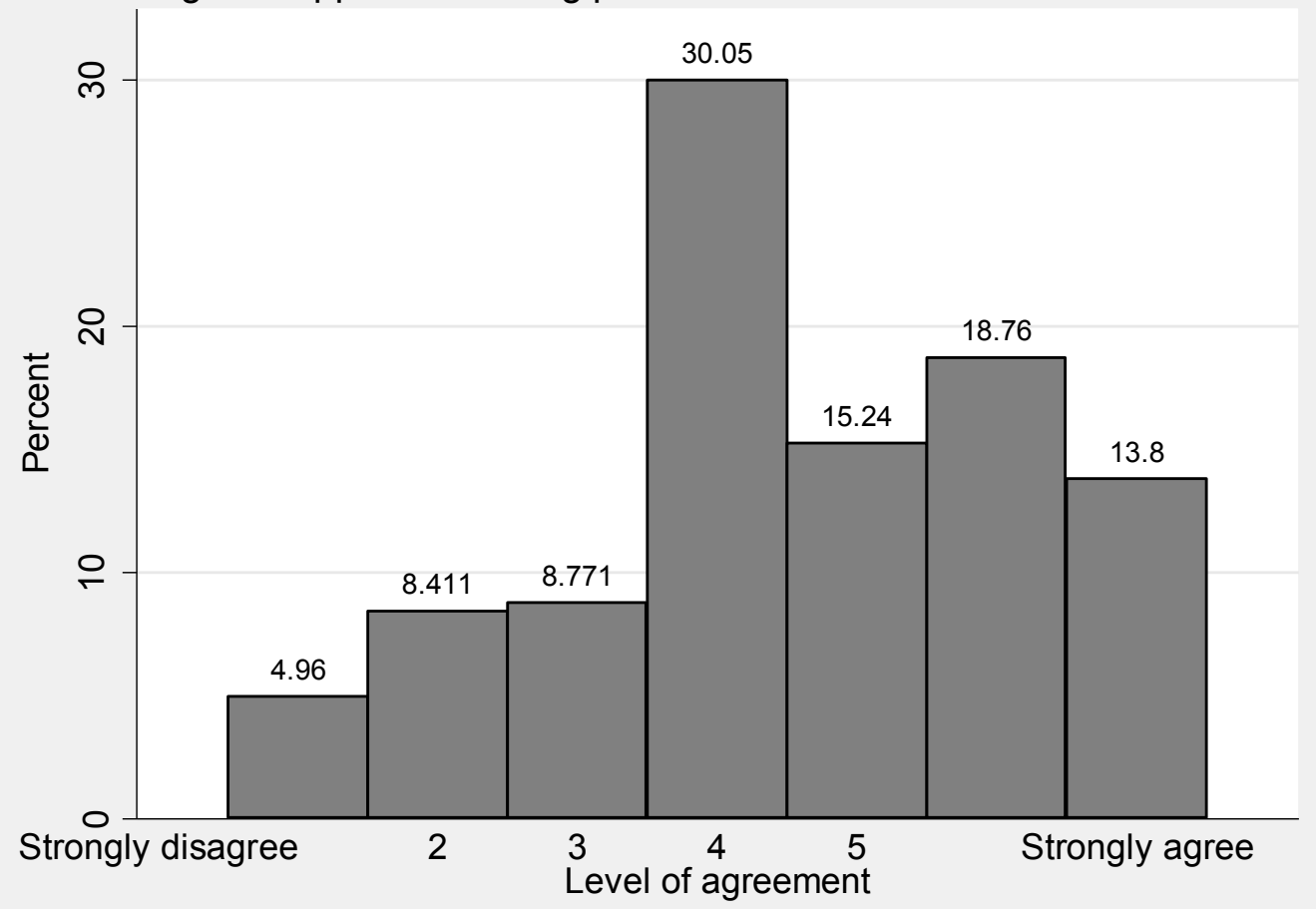




\section{Appendix 1}

Appendix 1-Odds ratios for all models.

\begin{tabular}{|l|c|c|}
\hline \multicolumn{2}{|c|}{ Table 1A. LECS sample - Odds ratios } \\
\hline & Model 1 & Model 2 \\
\hline Female & 2.31 & 2.25 \\
\hline Party candidate & 1.52 & - \\
\hline Feminist & 2.98 & 3.03 \\
\hline No opportunities from parties & 1.65 & 1.64 \\
\hline
\end{tabular}

\begin{tabular}{|l|c|c|}
\hline \multicolumn{2}{|c|}{ Table 1B. Professionals sample - Odds ratios } \\
\hline & Model 3 & Model 4 \\
\hline Female & 1.56 & 1.64 \\
\hline LR self-placement & 0.85 & - \\
\hline Feminist & 1.86 & 1.66 \\
\hline No opportunities from parties & 2.48 & 2.36 \\
\hline Women don't come forward & 1.37 & 1.37 \\
\hline Vote Fianna Fáil & - & 0.49 \\
\hline Vote Labour Party & - & 2.12 \\
\hline Vote Sinn Féin & - & 2.39 \\
\hline
\end{tabular}

\begin{tabular}{|l|c|c|}
\hline \multicolumn{2}{|c|}{ Table 1C. INES sample - Odds ratios } \\
\hline & Model 5 & Model 6 \\
\hline Female & 1.26 & 1.27 \\
\hline Feminist (proxy) & 1.46 & 1.45 \\
\hline Level of education & 0.87 & 0.87 \\
\hline Vote Fine Gael & - & 1.78 \\
\hline
\end{tabular}

